\title{
Improving Anticipative Learning through Entrepreneurial Orientation in Small to Medium Size Enterprises
}

\author{
Meutia $^{1}$, Tubagus Ismail ${ }^{2}$, and Nurul $\mathrm{Ummi}^{3}$
}

\begin{abstract}
:
Recently, SME becomes core business that is widely performed by Indonesian government. The more entrepreneurs, the better and stronger economy pillars in Indonesia. However, SME recently face many obstacles such as minimum product quality, packaging, marketing strategy and promotion. The biggest problem faced by SME in Indonesia is the lack of knowledge and learning process for SME managers.

The purpose of this study is to investigate the influence of social networking and entrepreneurial competence on entrepreneurial orientation and learning process. Learning process used in this study is anticipative learning. Criteria applied to choose respondent in this study is special product from SME in Banten Province, Indonesia. Respondents in this study are 105 persons. Analytical tool used in this study is Structural Equation Modeling (SEM) by using SmartPLS program.

The results from this study state that social networking and entrepreneurial competence positively and significantly influence entrepreneurial orientation and entrepreneurial orientation positively and significantly influence anticipative learning. The result from this study is expected to provide contribution to Resource Based View theory. Social networking and competence become inherited legacy to develop a business and it also becomes tacit knowledge to develop entrepreneurial orientation, so that it will create anticipative learning to improve SME that specializes in local product in Banten province, Indonesia.
\end{abstract}

Keywords: Small Medium Enterprises, Networking, Competence, Orientation, Learning Type of Paper: Empirical/ Review

\footnotetext{
${ }^{1}$ University of Sultan Ageng Tirtayasa, Jl. Raya Jakarta Km. 4, 42118, Serang, Indonesia

${ }^{2}$ University of Sultan Ageng Tirtayasa, Jl. Raya Jakarta Km. 4, 42118, Serang, Indonesia

${ }^{3}$ University of Sultan Ageng Tirtayasa, Jl. Raya Jakarta Km. 4, 42118, Serang, Indonesia
} 


\section{Introduction}

Recently, SME has become business potential that is encouraged by Indonesia government. The more entrepreneurs, the better and stronger economy pillars in Indonesia. Through SME, local resources, workers and funding will be better absorbed and optimally used (Sudiarta, 2014). Based on statistical data, SME (20142015) has business sector proportion as (1) farming, fishery, and forestry; (2) sale, hotel and restaurant sector; (3) manufacturing; (4) communication sector; and (5) service. Recently, SME face many obstacles such as minimum product quality, packaging, marketing strategy and promotion (Ismail, 2016). The biggest problem faced by SME in Indonesia is the knowledge and behavior of SME (Ismail, 2016; Havlíček et al., 2013; Břečková and Havlíček, 2013; Liapis et al., 2013; Thalassinos and Liapis, 2014; Frank et al., 2016; Kosinova et al., 2016).

Individual behaviors such as trait, motivation, believe, personal image, social role, knowledge and skill reflect the ability of how effective entrepreneurs perform business activity (Ismail, 2016). The ability of entrepreneur is reflected by manager's behavior and it becomes the most important thing to reach business growth (Farsi et al., 2013; Pociovalisteanu and Thalassinos, 2008). Competence, market orientation and learning had long been acknowledged as a source to reach competitive advantage (Ismail 2016). Entrepreneurial competence is considered as important factor to determine SME success (Ahmad et al., 2010). Business competence covers knowledge, skill and ability. Entrepreneurial competence is needed to start a business meanwhile managerial ability is needed to develop the business (Ahmad et al., 2010). Entrepreneurial competence comes from trait, character, attitude, social rule and self-image (Ahmad et al., 2010). Previous researches found out that there is no relationship between entrepreneurial orientation and learning process (Beneke et al., 2016), yet recent studies find out that entrepreneurial orientation positively influence organizational learning (Ismail, 2016; Kolchanova and Kolchanova, 2016; Bondarenko et al., 2017).

Many authors have studied the learning process in SME. Organizational learning developed in this study is anticipative learning. Anticipative learning accepts new point of view about new realities. This learning process will ease us to prepare ourselves in facing future with our creative thought and innovation (Chinowsky and Realph, 2007). Based on the explanation above, we will discuss about the influence of social networking and entrepreneurial competence on entrepreneurial orientation and their influence on anticipative learning. This paper is divided into five parts, introduction, literary review and hypothesis development, research method, result and discussion, and conclusion.

\section{Literature Review and Hypothesis Development}

\subsection{The Influence of Social Network on Entrepreneurial Orientation}


Social network is a part of social capital theory. Social capital is a valuable source for both individual and groups. Generally, there are eight distinctive elements to create social capital which are participation in social community, proactive in social contexts, trust and safety feeling, neighborhood connection, family and friend connection, tolerance of diversity, value of life, and work connection (Felício et al., 2014). Network is a relationship that becomes an entity with a set of social relationship such as friendship, informational exchange, cooperation, and knowledge sharing activity (Menelec and Jones, 2015). Closed social network will strengthen member cooperation ((Felício et al., 2014). Social network is a social relationship among members in an organization in a limited population (Ghauri et al., 2014).

Social network has two components: personal network and larger culture where the individual exist. Culture will influence the way of an individual interact in a certain social network. This network will grow trust and strengthen cooperation through formal and informal interaction among members (Menelec and Jones, 2015). Previous research that investigated social networking had found out positive relationship between social networking and entrepreneurial orientation (Chen et al., 2007; DeJordy, 2013; Ameh and Udu, 2016). Based on empirical result, we build the first hypothesis as follow:

H1: The higher social network, the higher entrepreneurial orientation will be.

\subsection{The influence of entrepreneurial competence on entrepreneurial orientation}

Competence is an organizational capability. Competence is valuable, rare and hard to imitate (Hitt et al., 2005). Personal competence covers knowledge, skill, ability, experience and individual personality in an organization. Organizational competence is closely tied to developing organizational process (Mascarell et al., 2013). Entrepreneurial competence is needed to start a business meanwhile managerial ability is needed to develop a business although competence needs entrepreneurial competence (Ahmad et al., 2010). Entrepreneurial competence is the decisive factor for business success (Ahmad et al., 2010). Entrepreneurial competence can be formed in knowledge, cognitive ability, self-management, administration, human resources, decision skill, leadership, opportunity recognition, and opportunity development (Mu, 2013).

Entrepreneurial orientation becomes entrepreneur's desire to learn, be independent, compete, and innovate, take risk and search opportunity (Mascarell et al., 2013). Entrepreneurial competence positively and significantly influences entrepreneurial activities (Covin and Wales, 2012). The result from Ferreira et al. (2014) showed that organizational life cycle, organizational resource, organizational capability, motivation and its environment will all influence entrepreneurial orientation. The result from Mascarell et al. (2013) concluded that entrepreneurial competence, which becomes the part of entrepreneurial capability, would positively and 
significantly influence entrepreneurial orientation. Based on the explanation above, the author proposes the next hypothesis as follows:

H2: The higher the entrepreneurial competence, the higher the entrepreneurial orientation will be.

\subsection{The relationship between entrepreneurial orientation and anticipative learning}

Entrepreneurial orientation tends to describe how entrepreneurs always learn to improve their ability to improve product quality. Innovative orientation describes how entrepreneurs will perform action that will lead to the creation of new ideas, proactive to search new opportunities and personal initiative to develop their business. Some research showed that there is a relationship between entrepreneurial orientation and organizational learning (Jenny et al., 2015; Real et al., 2006). Organizational learning is the process of creation, sharing and application of knowledge to perform changes and innovation in an organization so that they will produce optimum performance (Chinowksy and Realph, 2007). Beneke et al. (2016) explained that learning ability is the most important thing for an organization to develop sustainable performance. In this study, organizational learning refers to anticipative learning (Beneke et al., 2016). Anticipative learning is the process to learn by not only adapting with the situation but also exploring new opportunities (Nurhayati, 2009). The result from Nurhayati (2009) explained that entrepreneurial orientation influence anticipative learning in furniture industry in Indonesia (Nurhayati, 2009). Entrepreneurial oriented company will be much more attentive in learning orientation and perform anticipative learning (Jenny et al., 2015; Real et al., 2006). Based on the explanation above, the author proposes third hypothesis as follows:

H3: The higher the entrepreneurial competence, the higher the anticipative learning will be.

Figure 1 describes empirical relationship between social networking entrepreneurial competence, entrepreneurial orientation and anticipative learning.

Figre 1. Empirical model 


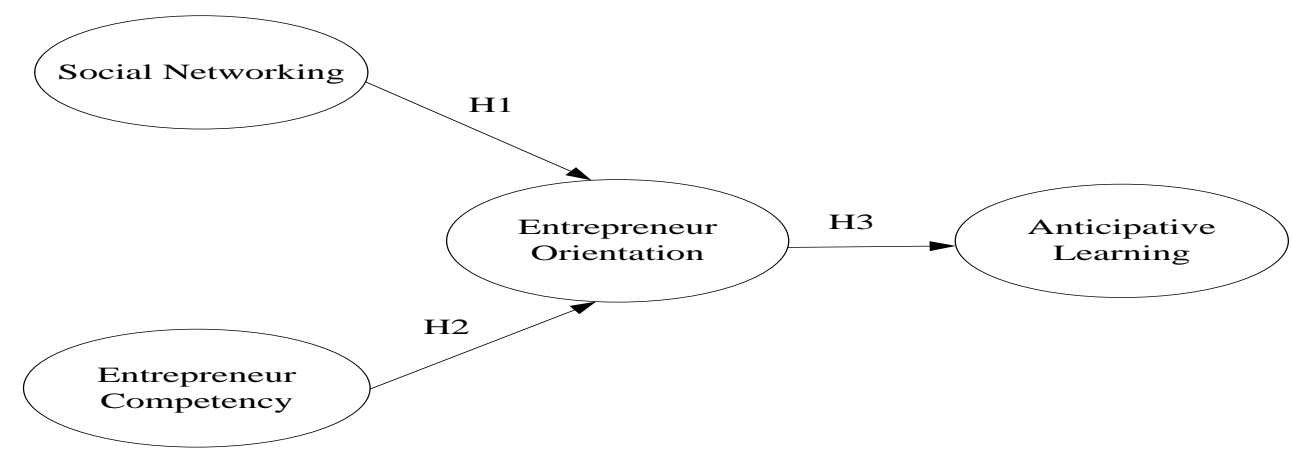

\section{Research Methodology}

Research method used in this study is survey method with distributed questionnaire as a tool to get data. Population in this study is the owner, manager of SME which specialize in local product in Banten Province, Indonesia. Sample used in this study is 105 respondents. Purposive sampling is used as sampling method in this study to draw respondents with criteria minimum 3 year experience. Data is collected by distributing questionnaire directly to respondents in 2016. Data is calculated by using Structural Equation Modeling (SEM) with SmartPLS program. This study is built on four variable, they are social networking, entrepreneurial competence, entrepreneurial orientation and anticipative learning.

Indicators used in this study to measure social networking variable come from Burt (2000), they are entrepreneurial networking (sn1), related entrepreneurial networking (sn2), and hierarchy entrepreneurial networking (sn3). Indicators used in this study to measure entrepreneurial competence variable come from Ahmad et al. (2010), they are conceptual competence (ec1), opportunity competence (ec2), leadership competence (ec3), relational competence (ec3), personal competence (ec4). Chandler and Jansen (1992) added technical competence (ec5) and ethical competence (ec6) and familiar competence (ec7). Indicators used in this study to measure entrepreneurial orientation are learning orientation (eo1), achievement orientation (eo2), autonomous orientation (eo3), aggressiveness orientation (eo4) and personal initiative (eo8). Learning variable has indicators from Murray (1989). Indicators used in this study to measure anticipative learning variable are the opportunity to perform experiment (al1), the improvement of technical knowledge (al2), focus on product development (al3), join exhibition and cooperation (al4).

\section{Result and Discussion}

\subsection{Descriptive Statistical Analyses}

Respondent used in this study is the manager or the owner of SME which specializes in producing and distributing local product in Banten Province, Indonesia. There are 
105 respondents, in which $70 \%$ of them come from manufacturing industry, $30 \%$ from sale industry and $20 \%$ from marketing industry.

\subsection{Structural Equation Modeling with SmartPLS}

In this study, the data will be analyzed by Structural Equation Modeling (SEM). SEM is one of multivariate analysis tool in social discipline. Multivariate analysis is the application of statistical method to analyze some variables simultaneously. Software used in this study to solve SEM problem is Partial Least Square (PLS). Hypotheses testing can be seen from t-statistical and probability value to know the influence among variables.

Table 1. Summary AVE, $\sqrt{ } A V E$ and $R$-Square

\begin{tabular}{|l|l|l|l|l|}
\hline Variable & $\begin{array}{l}\text { Average Variance Extracted } \\
\text { (AVE) }\end{array}$ & VAVE & $\begin{array}{l}\text { Composite } \\
\text { Reliability } \\
\text { (CR) }\end{array}$ & R-Square \\
\hline $\begin{array}{l}\text { Social } \\
\text { Networking }\end{array}$ & 0.786 & 0.887 & 0.925 & \\
\hline $\begin{array}{l}\text { Entrepreneur } \\
\text { Competency }\end{array}$ & 0.721 & 0.849 & 0.913 & \\
\hline $\begin{array}{l}\text { Entrepreneur } \\
\text { Orientation }\end{array}$ & 0.604 & 0.777 & 0.912 & 0.917 \\
\hline $\begin{array}{l}\text { Anticipative } \\
\text { Learning }\end{array}$ & 0.78 & 0.883 & 0.892 & 0.382 \\
\hline
\end{tabular}

Table 1 explained AVE value and $\sqrt{A V E}$ value from social networking, entrepreneurial competence, entrepreneurial orientation and anticipative learning constructs. Each construct has AVE value beyond 0.5, it shows that each construct has proper validity value. Each construct in this study has composite reliability value beyond 0.7 . It shows that internal consistency among variable has proper reliability value. In structural model, it can be based on R-square value. The higher R-square value, the larger independent variable will be. It will also explain dependent variable. As a result, the structural equation will be better. For entrepreneurial orientation variable has R-square value as 0,917 , it means that 91,7 variance of entrepreneurial orientation can be explained by social networking. Entrepreneurial competence will be explained by other variable outside this model.

Table 2. Hypothesis Result

\begin{tabular}{|l|l|l|l|l|l|l|l|}
\hline & & & $\begin{array}{l}\text { Original } \\
\text { Sample } \\
\text { Est. }\end{array}$ & $\begin{array}{l}\text { Mean } \\
\text { of } \\
\text { sample }\end{array}$ & $\begin{array}{l}\text { Standard } \\
\text { Deviation }\end{array}$ & $\begin{array}{l}\text { T- } \\
\text { Statistic }\end{array}$ & Hypothesis \\
\hline Soc. Networ. & $>$ & $\begin{array}{l}\text { Entre. } \\
\text { Orient. }\end{array}$ & 0,495 & 0.487 & 0.147 & 3.387 & Supported \\
\hline $\begin{array}{l}\text { Entre. } \\
\text { Compet. }\end{array}$ & --- & $\begin{array}{l}\text { Entre. } \\
\text { Orient. }\end{array}$ & 0.272 & 0.274 & 0.087 & 2.897 & Supported \\
\hline
\end{tabular}




\begin{tabular}{|l|l|l|l|l|l|l|l|}
\hline & --- & Anti. & & & & & \\
Entre. Orient. & $>$ & Learn. & 0.237 & 0.244 & 0.097 & 2.765 & Supported \\
\hline
\end{tabular}

\subsection{Hypothesis testing}

The result from hypothesis 1 testing shows that social networking variable positively and significantly influence on entrepreneurial orientation. It means that $\mathrm{H} 1$ is accepted. The result from hypothesis testing that analyze the relationship between social networking and entrepreneurial orientation provide statistical value as 3.387 and it is larger than required value as $>1,96$.

Social networking has an important role to market local product from SME. Social networking has developed well among SME owner to make good social relationship. In addition, it will ease and develop the relationship. Social relationship built on informal SME will have higher trust rate to face business environment. Social networking is made by social interaction among SME managers, especially in social relationship that will influence the development of business relationship. Entrepreneurs that have social networking will communicate more effectively and dynamically with other SME entrepreneurs. This communication will take a shape in both vertical communication like communication with the government, and horizontal communication like communication among individuals and other entrepreneurs. There are a lot of advantages can be got by building social networking to find new opportunities in product marketing.

Social networking will provide dynamic relationship among individuals or among groups both in businessperson and government to create business development. The results from this study support Chen et al. (2007) who stated that social networking which is a part of social capital variable will positively influence entrepreneurial orientation. The result from Ameh and Udu (2016) stated that organizational ability to develop inter-organizational relationship and entrepreneurial orientation will provide larger capability to get valuable resources and competitive advantage through social networking. This study supports DeJordy (2013), Ameh and Udu (2016) who stated that social networking will provide positive contribution on entrepreneurial orientation.

Entrepreneurial competence positively and significantly influence entrepreneurial orientation with t-statistical value as 2,897 and significant at 0,01 . It means that $\mathrm{H} 2$ is supported. Based on field study, entrepreneurial orientation, which is owned by entrepreneurs, will push the development of entrepreneurial orientation. Entrepreneurial competence comes from personal background (trait, character, behavior, social role and personal image) and people in working place (Ahmad et al., 2010). The result from this study supports Mascarell et al. (2013) who concluded that entrepreneurial competence is a part of entrepreneurial capabilities that will positively and significantly influence entrepreneurial orientation. 
The relationship between entrepreneurial orientation and anticipative leaning shows positive and significant relationship with t-statistical value as 2,765 . It means that $\mathrm{H} 3$ is supported. The result from field study also identifies that trait such as dare to take a risk, tend to find new ideas, tend to search opportunity, and aggressive will influence organizational learning. The higher the courage to take a risk, the higher anticipative learning will be. Entrepreneurs that likely to find new and fresh ideas to develop their business will also improve anticipative learning. Anticipative learning will be built on entrepreneur's ability to find business opportunity. It is supported by the study that showed positive influence from entrepreneurial orientation on anticipative learning which is a part of organizational learning (Real et al., 2006; Jenny et al., 2015; Nurhayati, 2009).

\section{Conclusion}

Based on the result and discussion, it can be concluded that 3 hypotheses measured in this study provide positive and significant influence. Social networking influence entrepreneurial orientation of SME owner. Social network enables business performer to share knowledge so that it will produce innovativeness, pro activeness and opportunity. Entrepreneurial competence also significantly influences entrepreneurial orientation.

Entrepreneurial orientation significantly influences anticipative learning. Entrepreneurial orientation will push entrepreneurs to get more learning process, especially in anticipating external environment such as market change, demand change, competitor and substitution. The result from this study provides contribution on Resource Based View theory in which competence and social networking has been tied closely and becomes entrepreneur's capability to develop their market. As a result, anticipative learning owned by SME manager will create a better product and effort to compete in a larger market.

\section{References}

Ahmad, N.H. Ramayah, T. Wilson, C. and Kummerow, L. 2010. Is entrepreneurial competency and business success relationship continget upon business environment ? a study of Malaysian SMES. International Journal of Entrepreneurial Behaviorand Research, 16(3), 182-203.

Ameh, A.A. and Udu, A.A. 2016. Social networks and entrepreneurship orientation among students in nigerian universities: a study of social network size and risk disposition. Business and Management Research Sciedu Press, 5(2), 1-11.

Beneke, J. Blampied, S. Dewar, N Soriano, L. 2016. The impact of market orientation and learning orientation on organisational performance: A study of small to medium-sized enterprises in Cape Town, South Africa. Journal of Research in Marketing and Entrepreneurship, Vol. 18 Issue 1, 90-108.

Bondarenko, G.T., Isaeva, A.E., Orekhov, S.A., Soltakhanov, U.A. 2017. Optimization of the Company Strategic Management System in the Context of Economic Instability. European Research Studies Journal, 20(2B), 3-24.

Břečková, P. and Havlíček, K. 2013. Leaders Management and Personnel Controlling in 
SMEs. European Research Studies Journal, 16(4), Special Issue on SMEs.

Burt, R.S. 2000. The network structure of social capital, in R.I. Sutton, and B.M. Greenwich Research in Organizational Behaviour, 22(1), 345-423.

Chandler, G.N. and Jansen, E. 1992. The founder's self-assessed competence and venture performance. Journal of Business Venturing, 7(3), 223-236.

Chen, C.N., Tzeng, L.C., Ou, W.M. and Chang, K.T. 2007. The relationship among social capital, entrepreneurial orientation, organizational resources and entrepreneurial performance for new ventures. Contemporary Management Research, 3(3), 231-241.

Chinowsky, P.M. and Realph, A. 2007. Learning organization in construction. Journal of management in engineering, 2(7), 781-790.

Covin, J.G. and Wales, W.J. 2012. The measurement of entrepreneurial orientation. Entrepreneurship: Theory \& Practice, 36 (4), 677-702.

DeJordy, R. 2013. Social network theory. entrepreneurial orientation. encyclopedia of management theory. volume one: sage reference.

Farsi, J.Y., Rezazadeh, A. and Najmabadi, A.D. 2013. Social capital and organizational innovation: the mediating effect of entrepreneurial orientation. Journal of Community Positive Practices, 13(2), 22-40.

Felício, J.A., Couto, E. and Caiado, J. 2014. Human capital, social capital and organizational performance. Management Decision, 52(2), 350-364.

Ferreira, J.J., Raposo, M.L. and Fernandes, C.I. 2014. Strategic entrepreneurial orientation and small business growth. IGI Global, ch010, 180-203.

Frank, V.E., Mashevskaya, V.O., Ermolina, V.L. 2016. Innovational Mechanism of Implementation of Cluster Initiatives in Business. European Research Studies Journal, 19(1), 179-188.

Ghauri, P. Tasavori, M. and Zaefarian, R. 2014. Internationalisation of service firms through corporate social entrepreneurship and networking. International Marketing Review, 31(6), 576-600.

Ghozali, I and Latan, H. 2014. Partial Least Squares: Concepts, Methods, and Applaications Using PLS 4.0. UNDIP Press, Semarang.

Havlíček, K., Thalassinos I.E. and Berezkinova, L. 2013. Innovation Management and Controlling in SMEs. European Research Studies Journal, 16(4), 57-70, Special Issue on SMEs.

Hitt, M.A. Ireland, R.D. and Hoskisson, D.L. 2005. Strategic Management, 6th ed., Thompson Southwestern.

Ismail, T. 2016. Culture control, capability and performance: evidence from creative industries in Indonesia. Asian Review of Accounting, 24 (2), 171-184.

Jenny, M., Ruiz-Jiménez, J. and Fuentes, M.M. 2015. Management capabilities, innovation, and gender diversity in the top management team: An empirical analysis in technology-based SMEs. Business Research Quarterly, 19: 107-121.

Kolchanova, A. and Kolchanova, P. 2016. Solving Enterprise Management Problem with Cluster Technologies and ERP - Systems (in the Context of Capital CSE System). European Research Studies Journal, 19(2), 299-306.

Kosinova, N.N., Tolstel, S.M., Sazonov, P.S. and Vaysbeyn, D.K. 2016. Development of Methodological Approach to Enterprise's Financial Strategy Based on Comprehensive Evaluation of its Strategic Potential. European Research Studies Journal, 19(2), 21 33.

Liapis, K., Rovolis, A., Galanos, C. and Thalassinos, I.E. 2013. The Clusters of Economic Similarities between EU Countries: A View Under Recent Financial and Debt Crisis. European Research Studies Journal, 16(1), 41-66. 
Mascarell, C.S., Garzon, D. and Knorr, H. 2013. Entrepreneurial and innovative competences, are they the same?, Management Decision, 51(5), 1084-1095.

Menelec, V. and Jones, B. 2015. Networks and marketing in small professional service businesses. Journal of Research in Marketing and Entrepreneurship, 17(2), 193-211.

Meutia. 2017. Proactive attitude and organizational performance. International Journal of Economic Perspectives, 11(1), 5-16.

$\mathrm{Mu}$, J. 2013. Networking capability, new venture performance and entrepreneurial rent. Journal of Research in Marketing and Entrepreneurship, 15(2), 101-123.

Murray, A.I. 1989. Top Management Group heteroginity firm Performance. Academy of Management Review, 23(2), 242-266.

Nurhayati, T. 2009. Entrepreneur orientation and social capital; strategy improving organizational performance. Ph.D Thesis UNDIP. Semarang.

Pociovalisteanu, M.D., Thalassinos, I.E. 2008. The beginning and some national particularities of liberalism. Metalurgia International, 13(2), Special Issue, 172-177.

Real, J.C. Real, A. and Roldan, J.L. 2006. Determinants of organizational learning in the generation of technological distinctive competencies. International Journal of Technology Management, 35(2), 284-307.

Sudiarta, I.P. Kirya, I.K. and Cipta, W. 2014. Analysis of factors affecting the performance of micro, small and medium enterprises in Bangli. E-Journal Bisma, 2(1), 15-30.

Thalassinos, I.E. and Liapis K. 2014. Segmental financial reporting and the internationalization of the banking sector. Chapter book in, Risk Management: Strategies for Economic Development and Challenges in the Financial System,(eds), D. Milos Sprcic, Nova Publishers, 221-255. 